\title{
Review Paper: The Bed Incline and Prevention of Venti- lator-Associated Pneumonia
}

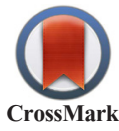

Tahereh Najafi Ghezeljeh ${ }^{1}$, Leila Kalhor ${ }^{*}$

1. Department of Intensive Care and Blood Circulation Technology, School of Nursing and Midwifery, Iran University of Medical Sciences, Tehran, Iran.

ditation: Najafi Ghezeljeh, T., \& Kalhor, L. 2016. The Bed Incline and Prevention of Ventilator-Associated Pneumonia. Journal of ClientCentered Nursing Care, 2(3), pp. 185-198. https://doi.org/10.32598/jccnc.2.3.185

: https://doi.org/10.32598/jcenc.2.3.185

Article info:

Received: 26 Nov. 2015

Accepted: 31 Mar. 2016

Keywords:

Ventilator-associated pneumonia, Elevated head of bed, Pressure ulcer, Intensive care unit

\begin{abstract}
A B S T R A C T
Background: Ventilator-Associated Pneumonia (VAP) is the most common nosocomial (hospital acquired) infection among patients undergoing mechanical ventilation. It increases mortality rate, duration of mechanical intubated ventilation, and hospitalization in the Intensive Care Units (ICUs). This review study aims to determine the proper gradient of a hospital bed in preventing VAP in patients hospitalized in ICUs.

Methods: In this study, research articles published from 1999 to 2016 were searched in PubMed, Science Direct, SID, and library sources, using keywords of "ventilator-associated pneumonia" and "elevated bed incline" and their corresponding terms in the Persian language.

Results: Results of the review showed that limited studies have been conducted on comparing the different inclines of bed and their effects on preventing VAP. Also, the available studies had methodological limitations or hospital staff failed to keep the patient in the same bed incline which was under the study for prolonged duration. Based on 19 reviewed studies, the incidence of VAP, hospital costs, mortality rate, and duration of mechanical ventilation in patients whose beds were inclined at 45 degrees or 30-45 degrees were significantly lower compared to patients reclining in the supine position. Although, in most conducted studies there were no consensus over a suitable bed incline in prevention of VAP and bedsore.
\end{abstract}

Conclusion: Raising the incline of bed can play a role in lowering the incidence of VAP, mortality rate, hospital costs and duration of mechanical ventilation. However, the proper gradient is not definite and requires studies with proper methodology in this regard.

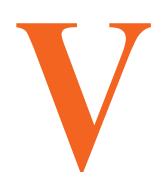

\section{Introduction}

entilator-Associated Pneumonia (VAP) is the most common hospital acquired infection and its incidence varies between $9 \%$ and $67 \%$ (Akin Korhan et al. 2014). VAP is an acquired pneumonia that develops in patients who have been undergoing mechanical ventilation for more than 48 hours

\section{* Corresponding Author:}

Lila Kalhor, MSc.

Address: Department of Intensive Care and Blood Circulation Technology, School of Nursing and Midwifery, Iran University of Medical Sciences, Tehran, Iran. Tel: +98 (912) 6647419

E-mail: leila.kalhor22@gmail.com 
(Taraghi et al. 2011). In other words, VAP and duration of mechanical ventilation increase mortality rate, and hospital costs, the stay at Intensive Care Units (ICUs) (Metheny et al. 2010). VAP is diagnosed with infiltration and the systemic symptoms of infection (including fever and elevated white blood cells and changes in sputum characteristics) (Niel-Weise et al. 2011).

Seven principal factors that can lower the incidence of VAP include elevating the head of the bed, rinsing the mouth with chlorhexidine, prophylaxis to prevent thrombosis, washing hands and preventing aspiration, reducing use of sedative drugs, and early weaning from mechanical ventilation. Therefore, one of the interventions that are normally carried out regarding patients undergoing mechanical intervention is to elevate head of bed relative to the flat surface and positioning the patient at a 30-degree angle or more relative to the supine position (Palmer et al. 2001). Because of VAP risk, it is recommended that the bed incline be set at 45 degrees. Others recommend that the head of bed should be elevated at 30 to 45 degrees (Bankhead et al. 2009). European Assembly of Experts has recommended that head of bed should be raised 20 to 45 degrees and preferably more than 30 degrees (Niel-Weise et al. 2011).

Based on Kollef et al. study (1997), the supine position (equal to or less than 30-degree incline) is a risk factor and may lead to VAP and even death in patients undergoing mechanical ventilation. They reported a significant correlation between the bed incline and incidence of VAP (Grap et al. 2005). A clinical trial study on comparing two bed inclines of 0 and 45 degrees showed a significant difference between them with regard to VAP incidence. Based on these study results, clinical guidelines recommended to use an incline of 30 degrees and more for prevention of VAP in patients on mechanical ventilation, and observing this instruction became a common instruction of nursing cares (Drakulovic et al. 1999).

In another study, a negative correlation was observed between incline of bed head and indexes of acute physiology and chronic health evaluation (APACHE II, a severity-of-disease classification system, Knaus et al., 1985, one of several ICU scoring systems. It is applied within 24 hours of admission of a patient to an intensive care unit: an integer score from 0 to 71 is computed based on several measurements; higher scores correspond to more severe disease and higher risk of death. The first APACHE model was presented by Knaus et al. in 1981). It was also reported that the incline of bed head of patients undergoing mechanical ventilation was lower than those having spontaneous breathing (Hanneman \& Gusick, 2005). In this regard, Grap et al. (2003) reported that the mean elevation of head of bed of 170 patients in ICUs was 19.2 degrees and its observation and follow up were poor. A study on 66 patients in critical condition showed that in $72 \%$ of occasions elevating the bed incline of less than 30 degrees was kept just for one day.

On the other hand, the clinical guidelines regarding preventing pressure ulcers have recommended that the bed incline should not be more than 30 degrees because elevating more than 30 degrees leads to an increase in shear force (Shearing forces are unaligned forces pushing one part of a body in one direction, and another part of the body in the opposite direction. When the forces are aligned into each other, they are called compression forces) and accordingly development of pressure ulcer. To limit this effect, especially in the sacral region, clinical guidelines have recommended that the bed incline should be less than 30 degrees (Schallom et al. 2014).

Although there are few studies available regarding the effect of bed incline on development of pressure ulcer as compared with VAP (Metheny et al. 2010), in a study on 20 healthy volunteers it was found that the maximum pressure in the sacral region was at the 45-degree incline $(\mathrm{P}<0.001)$. However, the low-airloss mattresses significantly reduce the pressure in all inclines (Lippoldt, Pernicka \& Staudinger, 2014) (P < 0.001). Pressure ulcer is often a complication of bed rest and patients hospitalized in ICUs are more prone to develop these types of injuries (Hyun et al. 2014). Considering the high incidence of bedsore in patients hospitalized in the intensive care units, paying attention to both issues and the proper bed incline seems necessary for their prevention.

Differences in clinical guidelines on the issue of VAP and pressure ulcer challenge health care staff regarding how to prevent both these costly hospital-acquired complications. Therefore, considering the conducted studies, the proper gradient of the bed for lowering the incidence of VAP and pressure ulcer in a patient hospitalized in ICU undergoing mechanical ventilation is not conclusive (Jackson et al. 2011). As a result, more studies should be conducted to examine the incidence of pneumonia and pressure ulcer at different inclines of the patient's bed, especially in patients hospitalized in ICUs undergoing mechanical ventilation and or having NG-tubes (Metheny et al. 2010).

However, most studies on the effect of semi-upright position in prevention of VAP and aspiration were done 
in previous decades with small sample sizes and did not compare different bed inclines which would help determine the proper bed incline (Metheny et al. 2010, NielWeise et al. 2011). In this regard, it seems that a review study needs to be conducted for identifying the process of studies on proper bed incline and prevention of VAP and pressure ulcer, their methodologies, limitations and eventually arriving at a decision regarding the proper incline of bed to prevent VAP and pressure ulcers (systematic review - a type of literature review that collects and critically analyzes multiple research studies or papers).

Likewise, a meta-analysis study was conducted to determine the impact of patient's reclining position on the incidence of pneumonia. In this analysis, 7 randomized clinical trial studies with a control group were examined. Results of the review study showed that the incidence of pneumonia among patients who were at 45 -degree in- cline position was significantly lower than patients who were in the supine position (Alexiou et al. 2009).

Another systematic review compared 3 randomized clinical trial studies with the control group and reported that the impact of 45-degree incline on the incidence of VAP was not conclusive and further investigations were needed in this regard. In addition, the researchers stated that there was insufficient information on the advantages and disadvantages of the using 45-degree bed incline for the patients undergoing mechanical ventilation was dependent on many factors (Niel-Weise et al. 2011).

Based on the latest review by Leng et al. (2012), the incidence of VPA among patients at 45-degree incline was significantly lower than patients with lower incline of their beds. However, whether this incline could have priority over other inclines, required more extensive

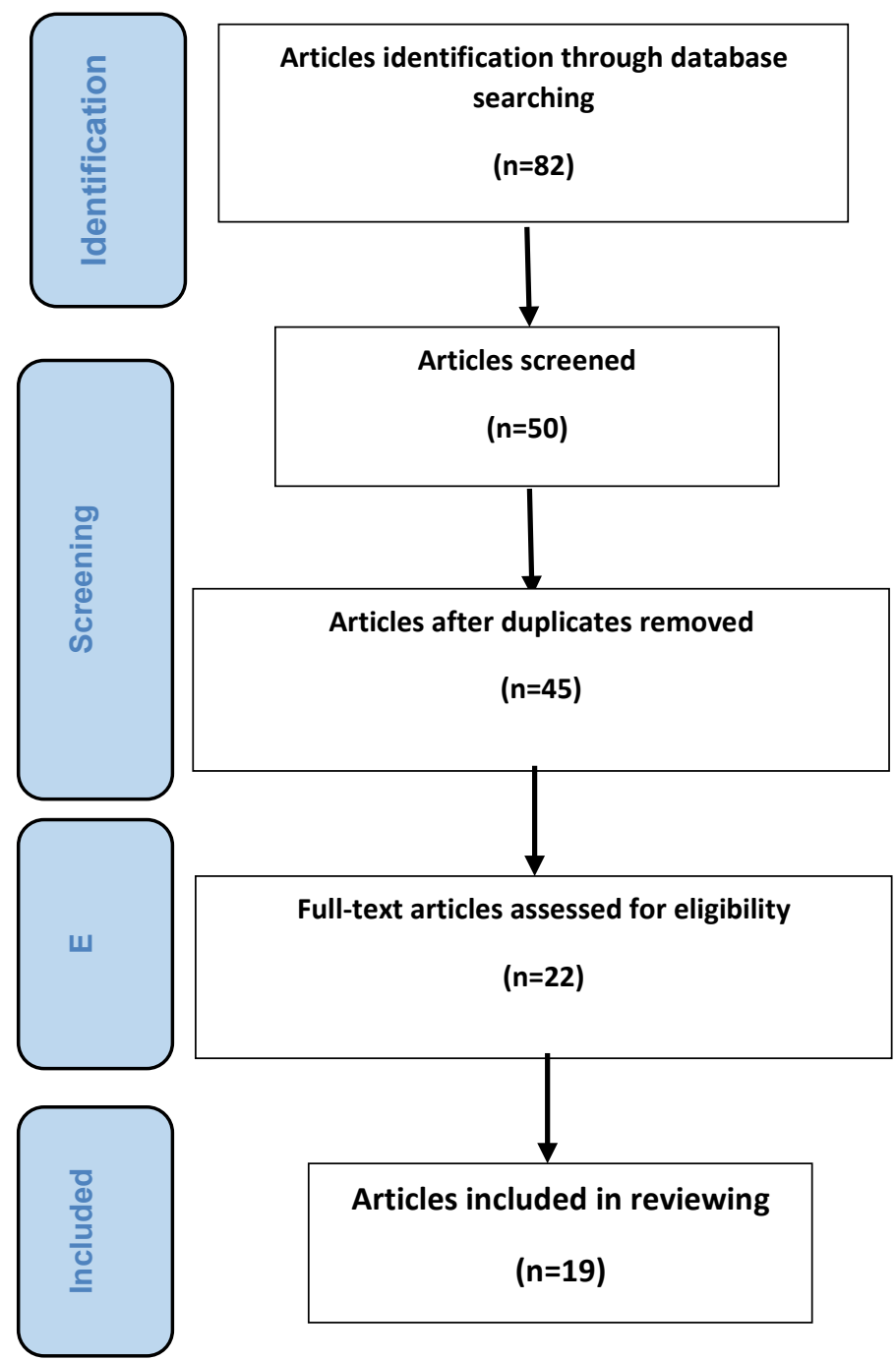

Figure 1. Search flowchart selection and articles' review 
studies. The following questions were considered in this review study:

1. In the studies, what bed inclines were examined for prevention of VAP and pressure ulcer, and what were the results?

2. How do health care workers observe proper bed incline for prevention of VAP and pressure ulcer and what factors were associated with it?

\section{Methods}

\section{Data source and search method}

This study examined and reviewed the studies conducted from 1999 to 2016 regarding the proper bed incline to prevent VAP through search and extraction from SID, PubMed, and Science Direct. Furthermore, library catalogue search, the reference control method, and also inquiries from experts on the research topic were sought and used. In this review, the keywords were "ventilatorassociated pneumonia," "elevation," "head of bed," "pressure ulcer," "intensive care units," and their Persian equivalents which were searched in the titles and abstracts.

These keywords were chosen by two experts in Nursery, and one of them searched the phrases related to proper bed incline in preventing VAP in databases. Then, another colleague re-examined and searched the sources and databases to be ensured of the adequacy of searched information and articles. This colleague who searched and extracted the articles were blind regarding the authors, the institutes, and the magazines that were subject to search.

\section{Criteria for selecting the articles}

Research articles were selected in both Persian and English articles on the prevention of VAP and pressure ulcer in ICUs that were published between 1999 and 2016. Articles that did not refer to the role of bed incline on the prevention of VAP, or referred to patients who were not undergoing mechanical ventilation were excluded from the review process.

Results of the search included 82 articles, out of which 45 articles covered the study subject, and by eliminating duplicate materials in different websites, 19 articles were found qualified for the review. Inclusion criteria comprised topics in connection with the bed incline in preventing VAP and pressure ulcer and articles referring to clinical guidelines on bed incline in preventing VAP and pressure ulcer. Figure 1 shows the search flowchart of selection and review of articles.

\section{Method for selecting the articles}

To determine the suitability of articles, first the title and the abstract of the articles were examined along with the time of study, then for further examination, all articles texts were studied by one of the researchers.

Thereupon, the following information was extracted by another researcher from the selected articles: type of the study, the hospital ward at which the study was carried out, and the year the study was conducted, sample size and method, statistical analysis and results of the study. The resulting information was evaluated by researchers and approved by resolving disputes through negotiations. A summary of the articles features are given in Table 1 .

\section{Features of reviewed studies}

\section{Type of study}

Assessment of knowledge in 2 studies, performance of nurses in 1 study, comparing different bed inclines in prevention of VAP in 14 studies, investigating the feasibility of elevating the bed incline in 1 study, and the programs for combining the bed incline with other methods in prevention of VAP in 5 studies were examined. Study methods comprised randomized control, prospective, descriptive, and retrospective.

\section{Study population and sample}

Four studies concentrated on the performance and knowledge of nurses working in ICUs, and other studies were conducted on patients hospitalized in ICUs undergoing mechanical ventilation. With regard to sample size, most studies had a sample size of less than 100 persons.

\section{Data collection method and tools}

Out of the articles, 3 studies had used the checklist for registering the mortality rate and duration of hospitalization. Most studies used the clinical pulmonary infection scoring (CPIS) for investigating the incidence of VAP. Scoring system of this tool is presented in Table 2. Other studies have used bacterial cultures, Hunter diagnostic criteria (similar to CPIS) and pepsin reagent strips, for identifying aspiration.

CPIS tool (Table 2) was discussed for the first time by Pugin et al. It includes six parameters: 1) temperature, 2) white blood cell count, 3) presence or absence of pulmonary secretions, 4) $\mathrm{PaO}_{2} / \mathrm{FiO}_{2}$ ratio, 5) chest Xray, and 6) results of smear and sputum culture with the semi-quantitative method. Each parameter has the score 
Table 1. List of the studies conducted on the bed incline and VAP in patients hospitalized in ICUs between 1999 and 2016

\begin{tabular}{|c|c|c|c|c|c|c|}
\hline No. & Study Title & Author & $\begin{array}{c}\text { The Study } \\
\text { Type }\end{array}$ & Sample Size & $\begin{array}{l}\text { Instru- } \\
\text { ment }\end{array}$ & Results \\
\hline 1 & $\begin{array}{l}\text { Supine } \\
\text { position, a } \\
\text { risk factor for } \\
\text { ventilator- } \\
\text { associated } \\
\text { pneumonia: } \\
\text { a randomized } \\
\text { study }\end{array}$ & $\begin{array}{l}\text { Drakulovic } \\
\text { et al. } 1999\end{array}$ & $\begin{array}{l}\text { Randomized } \\
\text { clinical trial } \\
\text { with control } \\
\text { group }\end{array}$ & $\begin{array}{l}86 \text { patients in } 2 \\
\text { groups of supine } \\
\text { position and } 45 \text { de- } \\
\text { grees (semi upright } \\
\text { position) }\end{array}$ & $\begin{array}{l}\text { Clinical } \\
\text { pulmonary } \\
\text { infection } \\
\text { score and } \\
\text { Braden } \\
\text { scale }\end{array}$ & $\begin{array}{l}\text { Pneumonia was significantly lower in } \\
\text { the semi-upright position. The highest } \\
\text { incidence of pneumonia was reported } \\
\text { in patients in supine position and } \\
\text { having NG-tube. No incidence of } \\
\text { pressure ulcer was reported. }\end{array}$ \\
\hline 2 & $\begin{array}{l}\text { Nursing care } \\
\text { in prevention } \\
\text { of ventilator- } \\
\text { associated } \\
\text { pneumonia }\end{array}$ & $\begin{array}{l}\text { Elorza } \\
\text { Mateos et } \\
\text { al. } 2011\end{array}$ & Descriptive & 26 patients & $\begin{array}{l}\text { Clinical } \\
\text { pulmonary } \\
\text { infection } \\
\text { score }\end{array}$ & $\begin{array}{c}\text { Oral hygiene was observed in } 23 \text { pa- } \\
\text { tients. In } 20 \text { patients, mean elevation } \\
\text { of bed was more than } 30 \text { degrees. In } \\
19 \text { patients, the endotracheal tube } \\
\text { cuff pressure was greater than } 20 \\
\text { mmHg. As a result of these measures } \\
\text { and also elevating head of bed by } \\
\text { approximately } 30 \text { to } 45 \text { degrees, the } \\
\text { incidence of pneumonia significantly } \\
\text { reduced. }\end{array}$ \\
\hline 3 & $\begin{array}{l}\text { The impact } \\
\text { of a protocol } \\
\text { to reduce the } \\
\text { level of aspira- } \\
\text { tion }\end{array}$ & $\begin{array}{l}\text { Metheney } \\
\text { et al. } 2010\end{array}$ & $\begin{array}{l}\text { Quasi- ex- } \\
\text { perimental }\end{array}$ & $\begin{array}{l}474 \text { patients: } \\
145 \text { patients in } 30 \\
\text { degrees incline, } \\
329 \text { patients in the } \\
\text { control group }\end{array}$ & $\begin{array}{l}\text { Clinical } \\
\text { pulmonary } \\
\text { infection } \\
\text { score }\end{array}$ & $\begin{array}{l}\text { The combination of elevating the } \\
\text { bed more than } 30 \text { degrees and use } \\
\text { of feeding tube in the small intestine } \\
\text { significantly reduced the incidence of } \\
\text { pneumonia. }\end{array}$ \\
\hline 4 & $\begin{array}{l}\text { Using multiple } \\
\text { cares to pre- } \\
\text { vent VAP }\end{array}$ & $\begin{array}{c}\text { Narang } \\
2008\end{array}$ & $\begin{array}{l}\text { Retrospec- } \\
\text { tive }\end{array}$ & 240 patients & $\begin{array}{l}\text { Clinical } \\
\text { pulmonary } \\
\text { infection } \\
\text { score }\end{array}$ & $\begin{array}{l}\text { Using multiple cares such as elevating } \\
\text { the bed incline by about } 30 \text { to } 40 \\
\text { degrees, and prophylaxis for prevent- } \\
\text { ing stomach ulcer and deep vein } \\
\text { thrombosis, significantly reduced } \\
\text { pneumonia. Duration of ventilation } \\
\text { also reduced. }\end{array}$ \\
\hline 5 & $\begin{array}{l}\text { Aspiration } \\
\text { of stomach } \\
\text { contents in } \\
\text { critically ill } \\
\text { patients with } \\
\text { NG-tubes }\end{array}$ & $\begin{array}{l}\text { Metheny } \\
\text { et al. } 2006\end{array}$ & Prospective & $\begin{array}{c}360 \text { patients: } 124 \\
\text { patients with the } \\
\text { bed incline more } \\
\text { than } 30 \text { degrees, } \\
\text { and } 226 \text { patients } \\
\text { with the bed } \\
\text { incline less than } 30 \\
\text { degrees }\end{array}$ & $\begin{array}{l}\text { Pepsin } \\
\text { reagent } \\
\text { strips }\end{array}$ & $\begin{array}{l}\text { In less than } 30 \text { degrees incline, } \\
\text { patients had a higher percentage of } \\
\text { aspiration, and this difference was } \\
\text { not significant. Also, in these patients, } \\
\text { the incidence of pneumonia was } \\
\text { significantly higher. The percent- } \\
\text { age of pepsin-positive trachea tube } \\
\text { secretions was also higher in these } \\
\text { patients. As a result, the bed incline } \\
\text { of less than } 30 \text { degrees is a risk } \\
\text { factor for developing aspiration and } \\
\text { pneumonia. }\end{array}$ \\
\hline 6 & $\begin{array}{l}\text { Predictors of } \\
\text { elevating the } \\
\text { bed }\end{array}$ & $\begin{array}{c}\text { Grap et al. } \\
2003\end{array}$ & Descriptive & 160 patients & $\begin{array}{l}\text { Clinical } \\
\text { pulmonary } \\
\text { infection } \\
\text { score }\end{array}$ & $\begin{array}{l}\text { Most patients were in the supine } \\
\text { position ( } 71 \%) \text { and a few were lying } \\
\text { face down (1\%). There was a signifi- } \\
\text { cant association between elevating } \\
\text { the bed and the systolic and diastolic } \\
\text { blood pressure. Regarding elevating } \\
\text { the bed, there was no association } \\
\text { between patients with NG-tubes with } \\
\text { patients without NG-tubes. The dif- } \\
\text { ference regarding elevating the bed } \\
\text { was associated with mechanical ven- } \\
\text { tilation. In patients under mechanical } \\
\text { ventilation, the bed incline was lower } \\
\text { than the other patients. }\end{array}$ \\
\hline
\end{tabular}




\begin{tabular}{|c|c|c|c|c|c|c|}
\hline No. & Study Title & Author & $\begin{array}{c}\text { The Study } \\
\text { Type }\end{array}$ & Sample Size & $\begin{array}{c}\text { Instru- } \\
\text { ment }\end{array}$ & Results \\
\hline 7 & $\begin{array}{l}\text { Possibility } \\
\text { and the im- } \\
\text { pact of 45-de- } \\
\text { gree incline } \\
\text { (semi-upright } \\
\text { position) in } \\
\text { preventing } \\
\text { ventilator- } \\
\text { associated } \\
\text { pneumonia }\end{array}$ & $\begin{array}{l}\text { van Nieu- } \\
\text { wenhoven } \\
\text { et al. } 2006\end{array}$ & Prospective & $\begin{array}{l}109 \text { patients in the } \\
\text { supine position and } \\
112 \text { patients in the } \\
\text { semi-upright posi- } \\
\text { tion ( } 45 \text { degrees) }\end{array}$ & $\begin{array}{l}\text { Cultures } \\
\text { obtained } \\
\text { by bron- } \\
\text { choscopy }\end{array}$ & $\begin{array}{l}\text { Ventilator-associated pneumonia } \\
\text { was reported in } 8 \text { patients in the } \\
\text { supine position, and in } 13 \text { patients in } \\
\text { the semi-upright position. The mean } \\
\text { of elevating the head of bed was } 9.8 \\
\text { degrees and } 16.1 \text { degrees on the first } \\
\text { day and seventh day in the group in } \\
\text { the supine position, respectively and } \\
28.1 \text { degrees and } 22.6 \text { degrees in the } \\
\text { first and seventh day for the group in } \\
\text { the semi-upright position, respec- } \\
\text { tively ( } P<0.001) \text {. The } 45 \text {-degree bed } \\
\text { incline was not achieved in } 85 \% \text { of } \\
\text { study duration and these patients had } \\
\text { much more change of positions than } \\
\text { patients in the supine position. }\end{array}$ \\
\hline
\end{tabular}

\begin{tabular}{|c|c|c|c|c|c|c|}
\hline 8 & $\begin{array}{c}\text { Elevating } \\
\text { the bed and } \\
\text { its impact } \\
\text { on stomach } \\
\text { reflux, aspira- } \\
\text { tion, pressure } \\
\text { ulcer }\end{array}$ & $\begin{array}{l}\text { Schallom } \\
\text { et al. } 2014\end{array}$ & Crossover & $\begin{array}{l}15 \text { patients, } 8 \text { pa- } \\
\text { tients in the inter- } \\
\text { vention group ( } 45 \\
\text { degrees) } 7 \text { patients } \\
\text { in the control group } \\
\text { ( } 30 \text { degrees) }\end{array}$ & $\begin{array}{l}\text { Pepsin } \\
\text { reagent } \\
\text { strips for } \\
\text { oral and } \\
\text { tracheal } \\
\text { secretions, } \\
\text { the Braden } \\
\text { Scale }\end{array}$ & $\begin{array}{l}188 \text { samples of oral secretions } \\
\text { were obtained, of them } 44 \% \text { were } \\
\text { pepsin-positive (pepsin-positive } \\
\text { secretions indicate reflux). } 174 \\
\text { samples of tracheal tube secretions } \\
\text { were also obtained, of which } 62 \% \\
\text { were pepsin-positive (pepsin-positive } \\
\text { secretions are signs of aspiration). } \\
\text { In the } 30 \text { degrees incline, pepsin } \\
\text { positive oral secretions were } 48.8 \% \\
\text { as compared with } 32.3 \% \text { in the } 45 \\
\text { degrees incline, and statistically, this } \\
\text { difference was not significant ( } P= \\
0.11 \text { ). At } 30 \text {-degree incline, pepsin- } \\
\text { positive tracheal tube secretions was } \\
69.4 \% \text { as compared with } 62.5 \% \text { at } \\
45-\text { degree incline, and this difference } \\
\text { was not statistically significant ( } P= \\
0.37 \text { ). No incidence of pressure ulcer } \\
\text { was observed. Therefore, patients by } \\
\text { using wavy mattresses at } 30 \text { degrees } \\
\text { or more inclines, can stay in bed for } \\
12 \text { to } 24 \text { hours without suffering from } \\
\text { pressure ulcer. }\end{array}$ \\
\hline 9 & $\begin{array}{l}\text { Lowering the } \\
\text { incidence of } \\
\text { ventilator- } \\
\text { associated } \\
\text { pneumonia } \\
\text { through } \\
\text { elevating the } \\
\text { head of bed }\end{array}$ & $\begin{array}{l}\text { Keeley } \\
2007\end{array}$ & $\begin{array}{l}\text { Randomized } \\
\text { clinical trial } \\
\text { with the con- } \\
\text { trol group }\end{array}$ & $\begin{array}{l}30 \text { patients entered } \\
\text { into this study, of } \\
\text { them } 17 \text { patients } \\
\text { were placed in the } \\
45 \text {-degree incline } \\
\text { and } 13 \text { patients } \\
\text { in the } 25 \text {-degree } \\
\text { incline }\end{array}$ & $\begin{array}{l}\text { Micro- } \\
\text { biological } \\
\text { testing } \\
\text { of clinical } \\
\text { symptoms }\end{array}$ & $\begin{array}{l}\text { Statistical results showed that } 5 \text { pa- } \\
\text { tients out of the } 45 \text {-degree group and } \\
7 \text { patients out of the } 25 \text {-degree group } \\
\text { became affected by ventilator-asso- } \\
\text { ciated pneumonia, and there was a } \\
\text { tendency of mitigation of pneumonia } \\
\text { in patients positioned in the } 45 \text {-de- } \\
\text { gree incline, although the difference } \\
\text { was not statistically significant. }\end{array}$ \\
\hline 10 & $\begin{array}{l}\text { The semi-up- } \\
\text { right position } \\
\text { in patients } \\
\text { connected to } \\
\text { mechanical } \\
\text { ventilation }\end{array}$ & $\begin{array}{c}\text { Rose et al. } \\
2010\end{array}$ & Prospective & 371 patients & $\begin{array}{c}\text { Clinical } \\
\text { symptoms, } \\
\text { Criteria of } \\
\text { Center for } \\
\text { Disease } \\
\text { Control, } \\
\text { Micro- } \\
\text { biological } \\
\text { tests, } \\
\text { 1SOFA (Se- } \\
\text { quential } \\
\text { (or Sepsis) } \\
\text { Organ } \\
\text { Failure As- } \\
\text { sessment } \\
\text { score) }\end{array}$ & $\begin{array}{l}\text { Pneumonia was reported in } 12 \text { pa- } \\
\text { tients ( } 3.2 \% \text { ). During } 7 \text { days of study, } \\
2112 \text { observations were made. The } \\
45 \text {-degree incline position or more } \\
\text { was seen in } 112 \text { observations ( } 3.5 \% \text { ). } \\
\text { In } 22.3 \% \text { of the occasions, the bed } \\
\text { incline was kept between } 30 \text { to } 45 \\
\text { degrees. The } 15 \text {-degres incline or less } \\
\text { was seen in } 353 \text { instances ( } 16.7 \%) \text {. } \\
\text { The head of bed was elevated mostly } \\
\text { when the patient was being weaned } \\
\text { from the mechanical ventilation and } \\
\text { was fed. Also, the bed incline was } \\
\text { mostly lowered in connection with } \\
\text { using inotrope agents and the lower- } \\
\text { ing of the mean arterial pressure. The } \\
\text { bed incline was also lower in patients } \\
\text { who were in critical conditions. }\end{array}$ \\
\hline
\end{tabular}




\begin{tabular}{|c|c|c|c|c|c|c|}
\hline No. & Study Title & Author & $\begin{array}{c}\text { The Study } \\
\text { Type }\end{array}$ & Sample Size & $\begin{array}{c}\text { Instru- } \\
\text { ment }\end{array}$ & Results \\
\hline 11 & $\begin{array}{l}\text { Effective } \\
\text { factors on the } \\
\text { bed incline in } \\
\text { the cardiac } \\
\text { surgery inten- } \\
\text { sive care units }\end{array}$ & $\begin{array}{l}\text { Ballew et } \\
\text { al. } 2011\end{array}$ & Descriptive & 100 patients & SOFA & $\begin{array}{l}\text { The head of bed was mostly lowered } \\
\text { when using vasopressor agents and } \\
\text { hemodynamic supportive factors. } \\
\text { Patients whose mean arterial pres- } \\
\text { sure was } 64 \mathrm{mmHg} \text {, their head of bed } \\
\text { was lower. }\end{array}$ \\
\hline 12 & $\begin{array}{l}\text { The combina- } \\
\text { tion of subglot- } \\
\text { tic secretions } \\
\text { drainage and } \\
\text { semi-upright } \\
\text { position for } \\
\text { prevention of } \\
\text { VAP }\end{array}$ & $\begin{array}{c}\text { Chen et al. } \\
2016\end{array}$ & Prospective & $\begin{array}{l}124 \text { patients: } 40 \\
\text { patients in the } \\
\text { semi-upright posi- } \\
\text { tion, } 39 \text { patients } \\
\text { in the subglottic } \\
\text { secretions drainage } \\
\text { group, } 43 \text { patients } \\
\text { in the semi-upright } \\
\text { position and sub- } \\
\text { glottic secretions } \\
\text { drainage group, } \\
\text { and } 42 \text { patients in } \\
\text { the control group }\end{array}$ & $\begin{array}{l}\text { Hunter } \\
\text { diagnostic } \\
\text { criteria }\end{array}$ & $\begin{array}{l}\text { The incidence of ventilator-associated } \\
\text { pneumonia has been reduced in } \\
\text { three intervention groups. Also in the } \\
\text { intervention group, there were fewer } \\
\text { instances of ventilator-associated } \\
\text { pneumonia; however, there were no } \\
\text { significant difference between the } \\
\text { groups regarding the mortality rate } \\
\text { resulting from ventilator-associated } \\
\text { pneumonia. }\end{array}$ \\
\hline 13 & $\begin{array}{l}\text { The effect } \\
\text { of elevating } \\
\text { bed on the } \\
\text { prevention } \\
\text { of ventilator- } \\
\text { associated } \\
\text { pneumonia }\end{array}$ & $\begin{array}{l}\text { Grap et al. } \\
2005\end{array}$ & Descriptive & $\begin{array}{l}\text { Examining } 66 \\
\text { patients under me- } \\
\text { chanical ventilation } \\
\text { for } 7 \text { days, a total of } \\
276 \text { observations }\end{array}$ & $\begin{array}{l}\text { Clinical } \\
\text { pulmonary } \\
\text { infection } \\
\text { score }\end{array}$ & $\begin{array}{l}\text { The mean elevation of head of bed in } \\
\text { the entire study was } 21.7 \text { degrees. El- } \\
\text { evating the head of bed did not have } \\
\text { a direct effect on clinical pulmonary } \\
\text { infection score. Incidence of pneu- } \\
\text { monia was higher among patients } \\
\text { who were in critical condition and } \\
\text { were positioned in an incline of } 30 \\
\text { degrees on the first day of mechanical } \\
\text { ventilation. }\end{array}$ \\
\hline 14 & $\begin{array}{l}\text { Impact of care } \\
\text { plan on the } \\
\text { prevention } \\
\text { of ventilator- } \\
\text { associated } \\
\text { pneumonia }\end{array}$ & $\begin{array}{l}\text { Ferreira et } \\
\text { al. } 2016\end{array}$ & Prospective & 188 patients & Checklist & $\begin{array}{c}\text { After implementing the checklist } \\
\text { items, the incidence of ventilator- } \\
\text { associated pneumonia, hospital costs, } \\
\text { and mortality significantly reduced ( } P \\
<0.01) \text {. }\end{array}$ \\
\hline 16 & $\begin{array}{l}\text { Education } \\
\text { alone is not } \\
\text { sufficient } \\
\text { to prevent } \\
\text { ventilator- } \\
\text { associated } \\
\text { pneumonia. } \\
\text { Multiple cares } \\
\text { are required. }\end{array}$ & $\begin{array}{l}\text { Hamishe- } \\
\text { hkar et al. } \\
2014\end{array}$ & $\begin{array}{c}\text { Observa- } \\
\text { tional }\end{array}$ & $\begin{array}{l}552 \text { checklists, } \\
\text { including } 294 \\
\text { observations prior } \\
\text { to training and } 258 \\
\text { observations after } \\
\text { training }\end{array}$ & Checklist & $\begin{array}{l}\text { Mean instances of ventilator-associ- } \\
\text { ated pneumonia before training was } \\
36.5 \% \text { and after training was } 41.2 \% \text {. } \\
\text { The bed incline of half of the patients } \\
\text { in both groups was less than } 30 \text { de- } \\
\text { grees prior and after training. Half of } \\
\text { nurses in the wards did not know that } \\
\text { the bed incline between } 30 \text { and } 45 \\
\text { degrees was important in prevention } \\
\text { of pneumonia. }\end{array}$ \\
\hline 16 & $\begin{array}{l}\text { The effect of } \\
\text { care programs } \\
\text { for upper re- } \\
\text { spiratory sys- } \\
\text { tem in preven- } \\
\text { tion of VAP } \\
\text { in patients } \\
\text { hospitalized in } \\
\text { the intensive } \\
\text { care units }\end{array}$ & $\begin{array}{l}\text { Bakhtiari } \\
\text { et al. } 2015\end{array}$ & $\begin{array}{l}\text { Randomized } \\
\text { clinical trial } \\
\text { with the con- } \\
\text { trol group }\end{array}$ & $\begin{array}{l}62 \text { patients: } 35 \\
\text { patients in the } \\
\text { intervention group } \\
\text { and } 37 \text { patients in } \\
\text { the control group }\end{array}$ & $\begin{array}{l}\text { Clinical } \\
\text { pulmonary } \\
\text { infection } \\
\text { score }\end{array}$ & $\begin{array}{l}\text { On the fifth day, the incidence of } \\
\text { ventilator-associated pneumonia } \\
\text { significantly reduced in the interven- } \\
\text { tion group (elevating head of bed by } \\
\text { about } 45 \text { degrees, drainage of subglot- } \\
\text { tal secretions, rinsing the mouth with } \\
\text { chlorhexidine } 2 \% \text {, and measuring the } \\
\text { cuff pressure up to } 25 \mathrm{~cm} \text { of water). }\end{array}$ \\
\hline
\end{tabular}




\begin{tabular}{|c|c|c|c|c|c|c|}
\hline No. & Study Title & Author & $\begin{array}{c}\text { The Study } \\
\text { Type }\end{array}$ & Sample Size & $\begin{array}{c}\text { Instru- } \\
\text { ment }\end{array}$ & Results \\
\hline 17 & $\begin{array}{l}\text { Knowledge } \\
\text { of ICU nurses } \\
\text { on prevention } \\
\text { of ventilator- } \\
\text { associated } \\
\text { pneumonia }\end{array}$ & $\begin{array}{l}\text { Korhan et } \\
\text { al. } 2013\end{array}$ & $\begin{array}{l}\text { Cross-sec- } \\
\text { tional }\end{array}$ & $\begin{array}{c}138 \text { ICU nurses in } \\
\text { Turkey }\end{array}$ & $\begin{array}{l}\text { The form } \\
\text { of nurses' } \\
\text { knowledge } \\
\text { regarding } \\
\text { clinical } \\
\text { guidelines } \\
\text { in preven- } \\
\text { tion of } \\
\text { VAP }\end{array}$ & $\begin{array}{l}\text { The nurses' knowledge was very poor } \\
\text { About } 29.7 \% \text { of them stated that the } \\
\text { semi-upright position was effective } \\
\text { in prevention of ventilator-associated } \\
\text { pneumonia. }\end{array}$ \\
\hline 18 & $\begin{array}{c}\text { Pressure } \\
\text { exerted on } \\
\text { body under } \\
\text { different bed } \\
\text { inclines with } \\
\text { different kinds } \\
\text { of wavy mat- } \\
\text { tresses }\end{array}$ & $\begin{array}{l}\text { Lippoldt et } \\
\text { al. } 2014\end{array}$ & Prospective & $\begin{array}{l}20 \text { healthy volun- } \\
\text { teers }\end{array}$ & $\begin{array}{c}\text { Xsensor } \\
\text { technol- } \\
\text { ogy }\end{array}$ & $\begin{array}{l}\text { The maximum pressure in the sacral } \\
\text { area was in the } 45 \text {-degree incline }(P \\
<0.001) \text {; however, the low air-loss } \\
\text { mattresses significantly lowered the } \\
\text { pressure under all inclines }(P<0.001)\end{array}$ \\
\hline 19 & $\begin{array}{l}\text { Comparing } \\
\text { the effect of } \\
\text { bed incline } \\
\text { at } 30 \text { and } 45 \\
\text { degrees in } \\
\text { prevention } \\
\text { of ventilator- } \\
\text { associated } \\
\text { pneumonia } \\
\text { in patients } \\
\text { hospitalized in } \\
\text { the intensive } \\
\text { care units }\end{array}$ & $\begin{array}{c}\text { Najafi Ghe- } \\
\text { zeljeh T et } \\
\text { al. } 2016\end{array}$ & $\begin{array}{l}\text { Randomized } \\
\text { clinical trial } \\
\text { with the con- } \\
\text { trol group }\end{array}$ & 120 patients & $\begin{array}{l}\text { Clinical } \\
\text { pulmonary } \\
\text { infection } \\
\text { scoring }\end{array}$ & $\begin{array}{l}\text { At the conclusion of the third day of } \\
\text { intervention, the incidence of ventila- } \\
\text { tor associated pneumonia was sig- } \\
\text { nificantly lower among patients who } \\
\text { were in the } 30 \text { - and } 45 \text {-degree bed } \\
\text { incline }(P<0.001) \text {. Also at } 45 \text {-degree } \\
\text { incline, the incidence of ventilator- } \\
\text { associated pneumonia was less than } \\
\text { that in } 30 \text {-degree incline. The three } \\
\text { groups did not have any statistically } \\
\text { significant difference with regard to } \\
\text { being affected by bedsore. }\end{array}$ \\
\hline
\end{tabular}

Client-Centered Nursing Care

of 0,1 , and 2, except the $\mathrm{PaO}_{2} / \mathrm{FiO}_{2}$ ratio which has the score of 0 and 2. Pugin and colleagues reported the sensitivity of tools as $93 \%$ and its specificity as $100 \%$ (Pugin et al. 1991). In most studies, digital or manual goniometer was used to measure the bed incline.

In a few studies, the simultaneous examination of pressure ulcer was also conducted. In these studies, Braden scale was used to anticipate pressure ulcer.

Only, in one study, the evaluation method of research tool has been reported with regard to its validity, reliability, sensitivity, and specificity (Akin Korhan et al. 2014). The Braden scale is used for anticipating pressure ulcer, and has been mentioned with 95\% confidence interval in a study (Serpa et al. 2011).

Braden scale includes 6 parameters and each parameter has 4 sections. If total score of a patient is $16-18$, it indicates low risk, 13-15 medium risk, 10-12 high risk, and less than 9 very high risk.

Every day, total scores for the patient should be computed and the patient' skin in pressure regions should be evaluated at each time his or her position changes, so that those patients at risk can be identified (Table 3).

\section{Results}

Knowledge and performance of ICU nurses and its related factors

A study conducted in Turkey with the aim of examining the level of knowledge of ICU nurses in prevention of VAP reported that the nurses' knowledge was very poor in a way that only $29.7 \%$ knew that 45 degrees incline of bed was effective in the prevention of VAP. They also reported that $68.80 \%$ of nurses were aware of the advantages of using closed suction system in prevention of VAP.

About $16.7 \%$ of nurses were aware of the time for changing the closed suction system in every patient and $23.90 \%$ of them were aware of the subglottic secretion drainage in prevention of VAP (Akin Korhan et al. 2014). Hamishekar et al. reported that training the nurses would not alone suffice to prevent VAP and multiple cares should be taken for patients undergoing mechanical ventilation to prevent VAP.

Therefore, the mean use of multiple cares to prevent VAP was $36.50 \%$ before training and $41.20 \%$ after training $(\mathrm{P}>$ $0.05)$. The bed incline for half of patients in both groups, before and after training, was less than 30 degrees. About $50 \%$ of nurses of ICUs did not know that the incline of 30 - 
Table 2. CPIS tool

\begin{tabular}{|c|c|c|}
\hline Parameter & Value & Score \\
\hline \multirow{3}{*}{ Temperature, ${ }^{\circ} \mathrm{C}$} & $36.5-38.4$ & 0 \\
\hline & $38.5-38.9$ & 1 \\
\hline & $39<, 36>$ & 2 \\
\hline \multirow{3}{*}{ White blood cell count } & $4000-11000$ & 0 \\
\hline & $11000<\cdot 4000>$ & 1 \\
\hline & $500<$ Band white blood cell & 2 \\
\hline \multirow{3}{*}{ Pulmonary secretions } & No pulmonary secretions & 0 \\
\hline & Nonsuppurative pulmonary secretions & 1 \\
\hline & Suppurative pulmonary secretions & 2 \\
\hline \multirow{2}{*}{ Oxygenation: $\mathrm{PaO}_{2} / \mathrm{FiO}_{2}$ ratio, $\mathrm{mmHg}$} & $\begin{array}{c}240>\text { or presence of ARDS (acute respiratory distress syndrome) } \\
\text { symptoms }\end{array}$ & 0 \\
\hline & $240<$ and absence of ARDS symptoms & 2 \\
\hline \multirow{3}{*}{ Chest radiography } & No infiltration & 0 \\
\hline & Diffused infiltration & 1 \\
\hline & Local infiltration & 2 \\
\hline \multirow{3}{*}{$\begin{array}{l}\text { Smear and sputum culture by semi-quantita- } \\
\text { tive method }\end{array}$} & No pathogenic bacteria in sputum culture $(+/ 0)$ & 0 \\
\hline & Pathogenic bacteria in sputum culture $(+++/++/+)$ & 1 \\
\hline & Some pathogenic bacteria are seen in the smear & 2 \\
\hline
\end{tabular}

Table 3. Braden Scale

\begin{tabular}{|c|c|c|c|c|c|c|}
\hline $\begin{array}{l}\text { Friction and } \\
\text { Shear }\end{array}$ & Nutrition & Mobility & Activity & Moisture & $\begin{array}{l}\text { Sensory Per- } \\
\text { ception }\end{array}$ & Score \\
\hline Without difficulty & Excellent & $\begin{array}{c}\text { Without restric- } \\
\text { tion }\end{array}$ & Often walks & Rarely moist & No impairment & 4 \\
\hline $\begin{array}{l}\text { Without apparent } \\
\text { difficulty }\end{array}$ & Sufficient & Partial restriction & $\begin{array}{c}\text { Occasionally } \\
\text { walks }\end{array}$ & $\begin{array}{l}\text { Occasionally } \\
\text { moist }\end{array}$ & Partial limitation & 3 \\
\hline Potential problem & $\begin{array}{l}\text { Probably insuf- } \\
\text { ficient }\end{array}$ & Very restricted & $\begin{array}{l}\text { Dependent on } \\
\text { chair }\end{array}$ & Very moist & Very limited & 2 \\
\hline Difficult & Very weak & $\begin{array}{l}\text { Completely im- } \\
\text { mobile }\end{array}$ & Dependent to bed & $\begin{array}{l}\text { Consistently } \\
\text { moist }\end{array}$ & $\begin{array}{l}\text { Completely } \\
\text { limited }\end{array}$ & 1 \\
\hline
\end{tabular}

45 degrees was important and vital to prevent pneumonia. Most nurses reported that they did not have sufficient time to perform preventive cares of VAP and the treatment system had not sufficiently provided them with necessary training in this regard (Hamishehkar et al. 2014).

The effect of multiple cares in prevention of VAP has been examined in 5 studies. In these studies, a combination of different interventions were used to prevent
VAP. In one study it has been reported that combined elevation of bed incline more than 30 degrees and use of nasogastric feeding tube significantly reduced VAP incidence. Results of the study showed that using combination programs such as elevating the bed incline about 30-45 degrees, subglottic secretion drainage, rinsing the mouth with chlorhexidine $2 \%$, and measuring the cuff pressure within $25 \mathrm{~cm}$ water, significantly 
reduced the incidence of VAP (Elorza Mateos et al. 2011; Bakhtiari et al. 2015).

Although in a study, the mortality rate among the group receiving multiple cares did not have significant difference with the control group (Chen Guihua et al. 2016), a significant reduction in mortality rate and hospital costs was reported in another study (Ferreira et al. 2016). Furthermore, in another study, the effect of combined intervention was demonstrated on lowering the incidence of VAP, duration of mechanical ventilation, and upper gastrointestinal bleeding (Narang 2008). Based on another study, the target of 45 degrees incline was not achieved in $85 \%$ of study duration and the reclining position of these patients have been changed far more than in patients in the supine position (van Nieuwenhoven et al. 2006).

In one study, the mean level of bed incline was 19.2 degrees and $70 \%$ of patients were in the supine position. No difference was found with regard to the elevation of the bed incline for starting the feeding among patients with tracheal intubation as compared with patients without endotracheal tube (Grap et al. 2003). In two other studies, it was also reported that patients under mechanical ventilation and in critical condition had a lower bed incline as compared with other patients (Grap et al. 2003; Rose et al. 2010).

Also, another study results showed that the bed incline of patients receiving vasopressor drugs $(\mathrm{P}=$ 0.001 ), patients under treatment with hemodynamic status supportive drugs ( 19 degrees vs. 26 degrees $\mathrm{P}=$ 0.01 ), and patients with median arterial pressure of 64 mmHg or less ( 17 degrees vs. 24 degrees $\mathrm{P}=0.01$ ) was lower than that of other patients. They demonstrated that the bed incline did not have any association with the nurses' working shifts, and lowering the patients' bed incline had no connection with the night shift. Grap et al. and Rose et al. in their studies came to this conclusion that the highest elevation of the bed incline was at the time of weaning the patient from mechanical ventilation and being fed.

Also, the greatest decrease in the bed incline was in association with the use of inotrope agents and lowering the mean arterial pressure. The reasons for not keeping patients at 45-degree incline included the nurses' inconvenience in carrying out cares, especially for critically ill patients at that incline, and also the difficulty in keeping the patients lying on their side (Grap et al. 2003; Rose et al. 2010). Other reasons for nurses' not observing the 45-degree bed incline included pa- tients' inconvenience, fear of making pressure ulcers, lacking sufficient information about clinical guidelines about elevating the bed incline to prevent VAP (Ballew et al. 2011). In another study, the nurses reported that the health system did not provide them with sufficient training, and due to shortage of health staff, nurses did not have sufficient time to carry out the required cares for the patients (Hamishehkar et al. 2014).

\section{Comparing different bed inclines in prevention of VAP}

Four studies reported that the incidence of VAP among patients at 45-degree bed incline was significantly lower than that in patients at lower inclines. Furthermore in several other studies, the inconclusive effect of 45 -degrees incline on VAP incidence and the need for further investigation in this regard were mentioned. Another study reported that in patients who were in lower than 30 degrees incline, the incidence of pneumonia was significantly higher (Metheny et al. 2006).

In another study, the highest incidence of pneumonia was reported in patients in the supine position as compared with patients at 45-degree incline and with NGtube. It was also reported that there was an association between semi-upright position and reduction of VAP incidence in patients hospitalized in ICUs undergoing mechanical ventilation (Drakulovic et al. 1999).

In a study, 30 patients hospitalized in ICU under mechanical ventilation were randomly divided into two groups of intervention (45-degree incline) and control group (25-degree incline). The study result showed that $29 \%$ of patients in the intervention group and $54 \%$ of patients in the control group were affected by VAP, although the difference was not statistically significant (Akin Korhan et al. 2014). Bakhriari et al. placed the patients in the intervention group under upper respiratory system care program, including keeping the patient at 45 degrees of incline. Endotracheal tube cuff pressure was also kept within the limit of $25 \mathrm{~cm}$ water, and prior to each position change, the tracheal tube secretions were suctioned off.

Until the fourth day, the incidence of VAP pneumonia did not show significant difference between the two groups; however, on the fifth day, the incidence of VAP in patients in the intervention group significantly reduced as compared with the control group (Bakhtiari et al. 2015). In Schallom et al. study, no statistically significant differences were observed between the 30 - and 45- degree bed incline regarding the incidence of aspiration and bedsore. 
Therefore, patients can be kept at 30 degrees or more incline by using low-air-loss mattresses, without occurrence of pressure ulcer. This study also suggested that keeping the patients at 30 degrees or more incline was feasible and easily tolerated by the patients and made no interference with performance of nursing cares. Prior to positioning the patients in the supine position or in the Trendelenburg position, nurses should examine and suction off the secretions of the mouth and trachea of the patients. Furthermore, patients receiving sedative drugs, should be positioned at least at 30 degrees of incline to reduce reflux and aspiration (Schallom et al. 2014).

In Najafi et al. study (2016), patients in the intervention group were positioned at 30-degree and 45-degree bed incline for three days but patients in the control group were positioned in the regular bed incline required by that hospital ward, and adjusted by nurses. Furthermore, all upper respiratory system and bedsore cares were carried out equally for all patients. Based on the results, the incidence of VAP significantly reduced among patients in the intervention group of 30- and 45-degree inclines $(\mathrm{P}<001)$ and the incidence of VAP at 45-degree incline was less than that in the 30-degree incline group. At the end of the third day, none of the patients in the intervention group (30- and 45-degree incline) contracted pressure ulcer (Najafi Ghezeljeh, Kalhor \& Haghani 2016).

Drakulovic et al. also investigated comorbidity of pressure ulcer with VAP incidence and concluded that patients at 45-degree incline had lower incidence of VAP and also no cases of pressure ulcer was reported in these patients (Drakulovic et al. 1999). However in Lippoldt et al. study on 20 healthy volunteers, the pressure exerted on various areas of the skin and sacrum and buttocks was measured at $0,10,30$, and 45 degrees on 4 types of wavy mattresses and in 6 positions of the supine, lying on the side, lying face down, the Trendelenburg position, reverse Trendelenburg position, and semi-upright position. The bed incline was measured by electronic goniometer. Pressure exerted on the sacrum region increased only at 45-degree incline $(\mathrm{P}<0.001)$. The reverse Trendelenburg position led to the lowest pressure exerted on the sacrum region under all inclines $(\mathrm{P}<0.01)$ (In the Trendelenburg position, the body is laid flat on the back with the feet higher than the head by 15-30 degrees, in contrast to the reverse Trendelenburg position, where the body is tilted in the opposite direction.). Heavier weight causes more pressure and more widespread contact of the body with mattresses and the use of low-air-loss mattresses also leads to distinct reduction of pressure. As a result, using low-air-loss mattresses accompanied with reverse Trendelenburg position and el- evating the bed head by about 30 to 45 degrees are very appropriate for preventing skin damage in the sacral area (Lippoldt, Pernicka \& Staudinger 2014).

\section{Discussion}

In this review study, 19 articles were reviewed regarding elevating the bed incline in prevention of VAP and pressure ulcer. Our review shows the limitation of studies on examining the impact of bed incline elevation in prevention of VAP and pressure ulcer. The studies that had compared different inclines in prevention of VAP recommended a bed incline of 45 degrees. However in most studies, the method of operation and modality of examining the variables, data collection tools and the method of assessing the reliability and validity of tools were not fully explained. Some studies briefly mentioned CPIS (Clinical Pulmonary Infection Score) tools and the Braden scale, however, they made no attempt to explain these tools.

In line with this review, Alexiou et al. in a review of 7 clinical trial studies showed that the incidence of pneumonia among patients at 45 -degree incline was significantly lower than patients in the supine position ( $27 \%$ vs. $47 \%)$ and the 15 - to 30 -degree incline was insufficient to prevent VAP in patients undergoing mechanical ventilation. Also, patients in 45-degree incline had a lower mortality rate compared with patients lying face down or in the supine position. However, the difference was not statistically significant ( $86 \%$ vs. $92 \%)$. Therefore, the 45-degree incline is one of the simplest and least costly methods for preventing VAP.

However, keeping the patients at 45-degree incline was difficult with regard to changing the patients' reclining position, and necessary training should be given to nurses about keeping the patients in this incline (Alexiou et al. 2009). Nevertheless, in Niel-Weise et al. review on 3 randomized clinical trial studies with the control group, the researchers did not have sufficient confidence in the advantages and disadvantages of the 45-degree incline and suggested further investigations in this regard. Also, the impact of elevating the bed incline to 45 degrees for 24 hours on the incidence of thromboembolism and hemodynamic instability is not clear (Niel-Weise et al. 2011).

Leng et al. in a meta-analysis showed that the incidence of VAP in patients at 45-degree incline was significantly lower than the control group (patients at a lower bed incline) $(\mathrm{P}=0.001)$. However, there were no significant differences regarding the mortality rate and 
length of hospitalization in ICU and treatment with antibiotics (Leng et al. 2012). Some studies also showed no significant differences between 30-degree and 45-degree inclines. Other studies referred to the point that patients hospitalized in ICUs, by using low-air-loss mattresses, can be positioned at 45-degree incline without being affected by pneumonia and pressure ulcer (Lippoldt, Pernicka \& Staudinger 2014).

The semi-upright position causes interference with nursing cares. Position change of patients to lying on their side was difficult for patients. Also nurses feared that patients could be affected by pressure ulcers. Whereas some studies have concluded that the semi-upright position was comfortably feasible by patients and had no interference with nursing cares. Some studies have also reported that the 15- to 30-degree incline was not sufficient to prevent VAP, and patients undergoing mechanical ventilation should be positioned at 45 -degree incline.

The awareness of nurses of preventing VAP by elevating the bed incline was poor. However, the result was positive after performing multiple cares. Review of studies related to the impact of multiple care programs in prevention of VAP confirms the better effectiveness of these cares in VAP prevention. Using combined applications such as elevating the bed about 30-45 degrees, draining subglottic secretions, rinsing the mouth with chlorhexidine $2 \%$, and measuring cuff pressure to within $25 \mathrm{~cm}$ water significantly reduces the incidence of VAP. In general, the following recommendations are offered for prevention of VAP:

- Keeping the bed incline at 30 to 45 degrees in patients undergoing mechanical ventilation and having NG-tube,

- Using wavy mattresses,

- Using noninvasive mechanical ventilation with positive pressure but with adequate precautions for patients with acute lung injury, acute respiratory failure, severe hypoxia, or severe acidemia,

- Using sedatives in low dosage,

- Daily examination of the patients to remove the endotracheal tube as soon as possible,

- Drainage of secretions above the endotracheal tube cuff,

- Maintaining the mechanical ventilation circuit and quickly changing it when fluid is seen in the circuit,
- Oral hygiene by using chlorhexidine and toothbrush twice a day,

- Peptic ulcer prophylaxis, and

- Continuous education and training of hospital staff on prevention and control of infection (Klompas et al. 2014).

Therefore, combination of these interventions in patients undergoing mechanical intervention should be emphasized and all nurses and physicians should be asked to carry out these cares. As such, more studies should be conducted in this field with larger sample sizes. Also, in many studies the feasibility and independent effect of 45-degree incline (semi-upright position) in prevention of VAP has not been examined yet. Some studies have reported that critically ill patients had lower inclined beds. Also, the patients' beds were mostly lowered at the time of weaning from the mechanical ventilator.

Regarding methodology, the conducted studies had some limitations. Some studies had small sample sizes. Also, in most studies blinding was not carried out (A blind - or blinded - experiment is an experiment in which information about the test is masked (kept) from the participant, to reduce or eliminate bias, until after a trial outcome is known. It is understood that bias may be intentional or unconscious, thus no dishonesty is implied by blinding. If both tester and subject are blinded, the trial is called a double - blind experiment) that could result in the Hawthorne effect (The Hawthorne effect, also referred to as the observer effect, is a type of reactivity in which individuals modify or improve an aspect of their behavior in response to their awareness of being observed.).

To prevent bedsore, the position of patients hospitalized in ICUs should be changed every two hours and as a result they may not be returned to the required bed incline. Resolving this issue needs exact measurement and recording of the bed incline. In some studies the bed incline was measured only three times a day and this can affect the accuracy of measuring the bed inclines and confidence in keeping the patients in those inclines. It is recommended that proper studies be conducted on continuous measuring the bed incline with digital tools, or using beds with incline marker. Also, in some studies that patients' beds incline was more than 30 degrees, a proper evaluation of patients' skin damage was not reported.

An exact method was not used for pneumonia diagnosis in most studies (such as bronchoscopy and preparation of sample for microbial culture). Since, in patients 
undergoing mechanical ventilation, the VAP does not develop until after 48-72 hours, the VAP diagnosis criteria such as fever, leukopenia or leukocytosis, infiltration in chest X-ray and microbial cultures should be performed routinely that usually cost little. On the other hand, in most studies, investigating pneumonia incidence was conducted after 72 hours to 5 days. It is recommended that studies be conducted on the longterm effects of keeping patients in various inclines on the incidence of VAP and clinical implications.

Meanwhile, the performance of nurses in compliance with elevating the bed incline for patients undergoing mechanical ventilation depends on general policies of the hospital (Grap et al. 2003). In order to prevent VAP, it is suggested that training programs be prepared for nurses working in the ICUs, and risks of lowering the patients' bed incline be taught to ICU nurses. Furthermore, studies should be conducted with the aim of identifying problems in keeping elevated the bed incline for patients undergoing mechanical ventilation, and measures should be adopted to reduce or remove these problems.

\section{Conclusion}

Based on reviewing the relevant articles, bed inclines of 30 to 45 degrees are appropriate for patients undergoing mechanical ventilation with NG-tube, and significantly reduce the incidence of VAP and aspiration as compared with patients in the supine position.

According to this review, the more is the bed incline, the less is the probability of pneumonia, and the 45-degree incline is preferable. Thus, the supine position is a risk factor for VAP, and nurses should consider this issue when changing the patient's position, although the studies that have been conducted in this regard are limited and have several methodological difficulties. On the other hand, in most studies, the effect of the bed incline on both VAP and bedsore was not investigated. Therefore, more randomized clinical trial studies with the control group should be conducted to examine the effects of different bed inclines on prevention of VAP and pressure ulcer, especially in patients who are in critical condition and undergoing mechanical ventilation with NG-tube.

\section{Acknowledgements}

The authors of this review study consider it necessary to express their gratitude to all those who have made writing of this article possible.

\section{Conflicts of Interest}

The authors of this study declared no conflict of interests.

\section{References}

Akin Korhan, E., Hakverdioglu Yont, G., Parlar Kilic, S. \& Uzelli, D. 2013. 'Knowledge levels of intensive care nurses on prevention of ventilator-associated pneumonia'. Nursing in Critical Care, 19(1), pp. 26-33. doi: 10.1111/nicc.12038.

Alexiou, V. G., Ierodiakonou, V., Dimopoulos, G. \& Falagas, M. E. 2009. 'Impact of patient position on the incidence of ventilator-associated pneumonia: A meta-analysis of randomized controlled trials'. Journal of Critical Care, 24(4), pp. 515-22. doi: 10.1016/j.jcrc.2008.09.003.

Bakhtiari, S., Yazdannik, A., Abbasi, S. \& Bahrami, N. 2015. 'The effect of an upper respiratory care program on incidence of ventilator-associated pneumonia in mechanically ventilated patients hospitalized in intensive care units'. Iranian Journal of Nursing and Midwifery Research, 20(3), pp. 354358. PMCID: PMC4462061

Ballew, C, Buffmire, M. V., Fisher, C., Schmidt, P., Quatrara, B., Conaway, M., \& Burns, S. M. 2011. 'Factors associated with the level of backrest elevation in a thoracic cardiovascular intensive care unit'. American Journal of Critical Care, 20(5), pp. 395-399. doi: $10.4037 /$ ajcc2011884

Bankhead, R., Boullata, J., Brantley, S., Corkins, M., Guenter, P., Krenitsky, J., et al. 2009. 'Enteral nutrition practice recommendations'. Journal of Parenteral and Enteral Nutrition, 33(2), pp. 122-67. doi: 10.1177/0148607108330314

Chen G., Wang J., Liu C., Xu R., Li Q., Zhou X., et al. 2016. A.S.P.E.N. 'Enteral nutrition practice recommendations'. Journal of Parenteral and Enteral Nutrition, 33(2), pp. 122-167. doi: /10.1177/0148607108330314

Drakulovic, M. B., Torres, A., Bauer, T. T., Nicolas, J. M. Nogue, S. \& Ferrer, M. 1999. 'Supine body position as a risk factor for nosocomial pneumonia in mechanically ventilated patients: a randomised trial'. Lancet, 354(9193), pp. 1851-1858. doi: 10.1016/s0140-6736(98)12251-1

Elorza Mateos, J., Ania Gonzalez, N., Agreda Sadaba, M., De Barrio Linares, M., Margall Coscojuela, M. A. \& Asiain Erro, M. C. 2011. 'Nursing care in the prevention of ventilatorassociated pneumonia'. 2011. Enfermería Intensiva, 22(1), pp. 22-30. doi: 10.1016/j.enfi.2010.11.006

Ferreira, C. R., De Souza, D. F., Cunha, T. M., Tavares, M. Reis, S. S. A., Pedroso, R. S. \& Röder, D. V. D. D. B. 2016 'The effectiveness of a bundle in the prevention of ventilator-associated pneumonia'. The Brazilian Journal of Infectious Diseases, 20(3), pp. 267-271. doi: 10.1016/j.bjid.2016.03.004

Grap MJ, Munro CL, Bryant S, Ashtiani B. 2003. 'Predictors of backrest elevation in critical care'. Intensive Critical Care Nursing, 19(2), pp. 68-74. PMID: 12706732 
Grap MJ, Munro CL, Hummel RS, Elswick RK, McKinney JL, \& Sessler CN. 2005. 'Effect of backrest elevation on the development of ventilator-associated pneumonia'. American Journal of Critical Care, 14(4), pp. 325-32. PMID: 15980424

Hamishehkar, H., Vahidinezhad, M., Mashayekhi, S. O., Asgharian, P., Hassankhani, H. \& Mahmoodpoor, A. 2014. 'Education alone is not enough in ventilator associated pneumonia care bundle compliance'. Journal of Research in Pharmacy Practice, 3(2), pp. 51-55. doi: 10.4103/2279-042X.137070

Hanneman, S. K. \& Gusick, G. M. 2005. 'Frequency of oral care and positioning of patients in critical care: A replication study'. American Journal of Critical Care, 14(5), pp. 37886. PMID: 16120889

Hyun, S., Li, X., Vermillion, B., Newton, C., Fall, M., Kaewprag, P., Moffatt-Bruce, S. et al. 2014. 'Body mass index and pressure ulcers: Improved predictability of pressure ulcers in intensive care patients'. American Journal of Critical Care, 23(6), pp. 494-501. doi: 10.4037/ajcc2014535.

Jackson, M., Mckenney, T., Drumm, J., Merrick, B., Lemaster, T. \& Vangilder, C. 2011. 'Pressure ulcer prevention in highrisk postoperative cardiovascular patients'. Critical Care Nurse, 31(4), pp. 44-53. doi: 10.4037/ ccn2011830

Keeley, L. 'Reducing the risk of ventilator-acquired pneumonia through head of bed elevation'. Nursing in Critical Care, 12(6), pp. 287-294. doi: 10.1111/j.1478-5153.2007.00247.x

Klompas, M., Branson, R., Eichenwald, E. C., Greene, L. R., Howell, M. D., Lee, G., et al. 2014. 'Strategies to prevent ventilator-associated pneumonia in acute care hospitals: 2014 update'. Infection Control \& Hospital Epidemiology, 35(2), pp. 133-154. doi: 10.1017/s0899823×00193894

Kollef, M. H., Prentice, D., Shapiro, S. D., Fraser, V. J., Silver, P., Trovillion, E., et al. 1997. 'Mechanical ventilation with or without daily changes of in-line suction catheters'. American Journal of Respiratory and Critical Care Medicine, 156(2), pp. 466-472. doi: 10.1164/ajrccm.156.2.9612083

Leng, Y. X., Song, Y. H., Yao, Z. Y. \& Zhu, X. 2012. 'Effect of 45 degree angle semirecumbent position on ventilator-associated pneumonia in mechanical ventilated patients: A metaanalysis'. Zhongguo Wei Zhong Bing Ji Jiu Yi Xue, 24(10), pp. 587-91. PMID: 23040773

Lippoldt, J., Pernicka, E. \& Staudinger, T., 2014. Interface pressure at different degrees of backrest elevation with various types of pressure-redistribution surfaces. American Journal of Critical Care, 23(2), pp. 119-126. doi: 10.4037/ ajcc2014670

Metheny, N. A., Clouse, R. E., Chang, Y. H., Stewart, B. J., Oliver, D. A. \& Kollef, M. H. 2006. 'Tracheobronchial aspiration of gastric contents in critically ill tube-fed patients: Frequency, outcomes, and risk factors'. Critical Care Medicine, 34(4) pp. 1007-1015. doi: 10.1097/01.ccm.0000206106.65220.59

Metheny, N. A., Davis Jackson, J. \& Stewart, B. J., 2010. Effectiveness of an aspiration risk-reduction protocol. Nursing Research, 59(1), pp. 18-25. doi: 10.1097/nnr.0b013e3181c3ba05

Najafi Ghezeljeh, T., Kalhor, L., \& Haghani, H. 2016. 'Comparing the effect head of bed elevation 30 and 45 degree on incidence of Ventilator Associated Pneumonia in patients admitted tointensive care units'. MSc thesis, Iran University of Medical Sciences,Tehran.
Narang, S. 2008. 'Use of ventilator bundle to prevent ventilator associated pneumonia'. Oman Medical Journal, 23(2), pp. 9699. PMCID: PMC3282421

Niel-Weise, B. S., Gastmeier, P., Kola, A., Vonberg, R. P., Wille, J. C. \& Van Den Broek, P. J. 2011. 'An evidence-based recommendation on bed head elevation for mechanically ventilated patients'. Critical Care, 15(2), pfp. 111. doi: 10.1186/ cc10135

Palmer, L. B., Albulak, K., Fields, S., Filkin, A. M., Simon, S. \& Smaldone, G. C. 2001. 'Oral clearance and pathogenic oropharyngeal colonization in the elderly'. American Journal of Respiratory and Critical Care Medicine, 164(3), pp. 464-468. doi: 10.1164/ajrccm.164.3.2008149

Pugin, J., Auckenthaler, R., Mili, N., Janssens, J. P., Lew, P. D. \& Suter, P. M. 1991. 'Diagnosis of ventilator-associated pneumonia by bacteriologic analysis of bronchoscopic and nonbronchoscopic "blind" bronchoalveolar lavage fluid'. American Review of Respiratory Disease, 143(5), pp. 1121-1129. doi: 10.1164/ajrccm/143.5_pt_1.1121

Rose, L., Baldwin, I., Crawford, T. \& Parke, R. 2010. 'Semirecumbent positioning in ventilator-dependent patients: a multicenter, observational study'. American Journal of Critical Care, 19(6), pp. 100-108. doi: 10.4037/ajcc2010783

Schallom, M., Dykeman, B., Metheny, N., Kirby, J. \& Pierce, J. 2014. 'Head-of-bed elevation and early outcomes of gastric reflux, aspiration and pressure ulcers: A feasibility study'. American Journal of Critical Care, 24(1), pp. 57-66. doi: 10.4037/ajcc2015781

Serpa, L. F., Santos, V. L., Peres, G. R., Cavicchioli, M. G. \& Hermida, M. M. 2011. 'Validity of the Braden and Waterlow subscales in predicting pressure ulcer risk in hospitalized patients'. Applied Nursing Research, 24(4), pp. 23-28. doi: 10.1016/j.apnr.2010.05.002

Taraghi Z., Darvishi Khezri H., Gholipour Baradari A., Heidari Gorji M. A., Sharifpour A., \& Ahanjan, M. 2011. Evaluation of the antibacterial effect of persica mouthwash in mechanically ventilated Icu patients: A double blind randomized clinical trial. Middle-East Journal of Scientific Research. 10(5), pp. 631-637.

Van Nieuwenhoven, C. A., Vandenbroucke-Grauls, C., Van Tiel, F. H., Joore, H. C., Van Schijndel, R. J., Van Der Tweel, I., et al. 2006. 'Feasibility and effects of the semirecumbent position to prevent ventilator-associated pneumonia: A randomized study'. Critical Care Medicine, 34(2), pp. 396-402. Available at: doi: 10.1097/01.ccm.0000198529.76602.5e 